American Journal of Biochemistry and Biotechnology 3 (3): 167-170, 2007

ISSN 1553-3468

(C) 2007 Science Publications

\title{
Platelet Derived Growth Factor-A mRNA Levels in Diabetic and Nondiabetic Subjects at Risk of Coronary Heart Disease
}

\author{
Salman A. H. Alrokayan \\ Department of Biochemistry, College of Science, King Saud University, \\ Riyadh 11451, Kingdom of Saudi Arabia
}

\begin{abstract}
Coronary heart disease (CHD) is the number one cause of death in developed countries. We investigated the quantity of platelet derived growth factor-A mRNA (PDGF-A mRNA) among four different groups of diabetic and nondiabetic Saudi subjects $(n=40)$ at risk of CHD. Total RNA was derived from peripheral blood mononuclear cells (PBMN) and PDGF-A mRNA reverse transcribed into cDNA in the presence of internal standard (cRNA) and amplified by competitive reverse transcriptase polymerase chain reaction (cRT-PCR). The gel was silver stained after polyacrylamide gel electrophoresis (PAGE) and PDGF-A mRNA quantitated by scanning densitometry. We demonstrate a significantly high expression of PDGF-A mRNA in hyperlipidaemic and diabetic subjects $\left(41 \pm 4 \times 10^{4}\right.$ copies/ $\mu$ g of RNA) compared to normal healthy individuals $\left(29.3 \pm 5 \times 10^{4}\right.$ copies/ $\mu \mathrm{g}$ of RNA). These findings suggest an important role of PDGF-A mRNA in progression of CHD among diabetics.
\end{abstract}

Key words: PDGF-A, mRNA quantitation, cRT-PCR, CHD, Diabetes mellitus, Atherosclerosis.

\section{INTRODUCTION}

In Western population, coronary heart disease (CHD) is a leading cause of death ${ }^{[1]}$ and its incidence is increasing in the Arab world including Kingdom of Saudi Arabia. CHD results from a disease process called atherosclerosis and several associated factors have been reported. The in vivo studies support the idea that platelet-derived growth factor (PDGF) may be involved in atherosclerosis ${ }^{[2-4]}$. Some previous studies have shown a high expression of PDGF-A gene in individuals with atherosclerosis and a two fold increase in plasma PDGF was found in hypercholesterolaemic patients with proven coronary atherosclerosis ${ }^{[5,6]}$. The biological properties of PDGF include stimulation of DNA synthesis, cell migration, endocytosis and secretion of matrix components ${ }^{[7]}$. PDGF from human platelets is a cationic glycoprotein of $M r \approx 30,000^{[8,9]}$. The purified PDGF is a dimer of two polypeptides, designated $\mathrm{A}$ and $\mathrm{B}$, the products of related but separate genes. cDNA encoding the A chain of PDGF was first isolated from a malignant glioma cell line. The A-chain is encoded by a gene located on chromosome 7 (7pter$7 \mathrm{q} 22)^{[10]}$.
The previous reports showed vast differences in CHD mortality rates among different populations and ethnic groups. Some populations still have low rates of CHD mortality, while others have a high incidence ${ }^{[11-}$ ${ }^{13]}$. This difference has mainly been attributed to existence of varying levels of risk factors in different populations and diabetes is one of these $\mathrm{e}^{[14]}$. The very high frequency of CHD among diabetic patients is common and ascribed partly to extensive presence of atherosclerotic plaques ${ }^{[1,15]}$. The opinion also prevails that diabetes accelerates the mechanism that leads to development of classical atherosclerosis and diabetic subjects with high cholesterol are generally at very high risk of developing $\mathrm{CHD}^{[16]}$. Limited information is available on the influence of known cardiovascular risk factors on stroke mortality in diabetic persons, and the available results are conflicting too ${ }^{[17]}$.

Several researchers have used reverse transcriptase polymerase chain reaction (RT-PCR) to study the response of various stimuli that influence the mRNA levels ${ }^{[18-20]}$, and PDGF-A mRNA ${ }^{[21]}$. We investigate the role of PDGF-A in various groups of subjects by quantification of PDGF-A mRNA concentration using cRT-PCR and Silver staining of the polyacrylamide gel

Corresponding Author:

Dr. Salman Al Rokayan, Department of Biochemistry, College of Science, King Saud University, P.O. Box 2455, Riyadh 11451, Kingdom of Saudi Arabia. 
electrophoresis (PAGE). In order to investigate the role of PDGF-A in individuals with or without diabetes and hypercholesterolaemia at risk of CHD, we determined the PDGF-A mRNA in at risk subjects and compared the results with controls. Determination of these risk factors may help to provide a better understanding of the underlying mechanism to adopt appropriate measures to avoid the disease and planning adequate treatment strategy.

\section{MATERIALS AND METHODS}

Subjects and samples: Blood samples were collected in $10 \mathrm{ml}$ EDTA tubes from 40 individuals (mean age at investigation 39, range 32-44 years) attending King Khalid University Hospital (KKUH), Riyadh. Subjects were categorized in four groups on the basis of medical history and blood chemistry $(\mathrm{n}=10$ in each group comprised 5 male and 5 female subjects). Group 1 (controls), healthy non smoking volunteers without a family history of premature CHD with normal glucose and cholesterol levels; group 2, diabetes with normal cholesterol levels; group 3, no diabetes with high cholesterol; and group 4, diabetes and high cholesterol. Medical history, glucose and cholesterol levels were provided by KKUH.

Isolation of total cellular RNA: The RNA was isolated by the method of Chomezynski and Sacchi ${ }^{[22]}$ from peripheral blood mononuclear cells (PBMN) by adding $10 \mathrm{ml}$ of EDTA blood on the Ficoll-Paque (Pharmacia Biotech) followed by centrifugation at $4000 \mathrm{~g}$ for $20 \mathrm{~min}$ at $4^{\circ} \mathrm{C}$. The pellet was homogenized with $1 \mathrm{ml}$ of solution $\mathrm{D}$ (4 $\mathrm{M}$ guanidinium isothiocyanate, $25 \mathrm{mM}$ sodium citrate, $\mathrm{pH} 5.2,0.5 \% \mathrm{~N}$ lauryl sarcosine, $0.1 \mathrm{mM}$ DTT and $0.1 \mathrm{mM} 2-$ mercaptoethanol). Sequentially, $0.3 \mathrm{ml}$ of $2 \mathrm{M}$ sodium acetate $(\mathrm{pH} 4.0), 3 \mathrm{ml}$ water saturated phenol $(\mathrm{pH} 4.0)$ and $0.6 \mathrm{ml}$ of choloroform-isoamyl alcohol (49:1) were added to the homogenized pellet. The aqueous phase was separated by centrifugation at $4,000 \mathrm{~g}$ for $20 \mathrm{~min}$ at $4^{\circ} \mathrm{C}$, precipitated with 0.6 volume of isopropanol and washed in $75 \%$ ethanol. Finally, RNA was dissolved in $20 \mu \mathrm{l}$ DEPC (diethyl-pyrocarbonate) treated sterile deionized (DI) $\mathrm{H}_{2} \mathrm{O}$ and stored at $-70^{\circ} \mathrm{C}$ until analyzed. RNA concentration was measured spectrophotometrically at $260 \mathrm{~nm}$ by diluting $1 \mu \mathrm{l}$ of RNA in $249 \mu \mathrm{l}$ of sterile DI $\mathrm{H}_{2} \mathrm{O}$ using GeneQuant-II (Pharmacia Biotech).

cDNA Sysnthesis: GeneAmp®RNA PCR kit (Perkin Elmer) was used for reverse transcription reaction. Briefly, $4 \mu \mathrm{l}$ of $25 \mathrm{mM} \mathrm{MgCl} 2,2 \mu \mathrm{l}$ of $10 \mathrm{X}$ PCR buffer
II (500 mM KCl, $100 \mathrm{mM}$ Tris- $\mathrm{HCl}, \mathrm{pH} 8.3), 2 \mu \mathrm{l}$ of each $10 \mathrm{mM}$ dNTP (dGTP, dATP, dTTP and dCTP), 1 $\mu \mathrm{l}$ of $20 \mathrm{U} / \mu \mathrm{l}$ RNAse inhibitor, $1 \mu \mathrm{l}$ of $50 \mathrm{U} / \mu \mathrm{l} \mathrm{MuLV}$ Reverse Transcriptase, $1 \mu$ of $50 \mu \mathrm{M}$ random hexamer and $1 \mu \mathrm{l}(5-25 \mathrm{ng})$ of cellular RNA, $1 \mu \mathrm{l}\left(10^{6}\right.$ copies $)$ of pAW109 RNA were added in a $0.2 \mathrm{ml}$ PCR tube. The total reaction volume was made up to $20 \mu \mathrm{l}$ with DEPC treated $\mathrm{DI} \mathrm{H}_{2} \mathrm{O}$ and incubated at room temperature for $10 \mathrm{~min}$ for hexameric primers extension. The reaction tubes were then incubated for reverse transcription using a thermal cylcler (Techne GENIUS, UK) at $42^{\circ} \mathrm{C}$ for $15 \mathrm{~min}$, denatured at $99^{\circ} \mathrm{C}$ for $5 \mathrm{~min}$ and cooled at $4^{\circ} \mathrm{C}$ for $5 \mathrm{~min}$.

Polymerase Chain Reaction (PCR): PCR amplifycation was carried out by using $10 \mu \mathrm{l}$ of cDNA synthesized by reverse transcription with $2 \mu$ of $25 \mathrm{mM}$ $\mathrm{MgCl}_{2}, 4 \mu \mathrm{l}$ of $10 \mathrm{X}$ PCR buffer II, $32.75 \mu \mathrm{l}$ of DEPC treated DI $\mathrm{H}_{2} \mathrm{O}, 0.5 \mu \mathrm{l}$ of $15 \mu \mathrm{M}$ PDGF-A each forward (AW116, 5'-CTGCCATTCGGAGGAAGAG-3'), and reverse primer (AW117, 5'-TTGGCCACCTTGACGC TGCG-3'), and $0.25 \mu \mathrm{l}$ of $5 \mathrm{U} / \mu \mathrm{l}$ AmpliTaq ${ }^{\circledR}$ DNA polymerase. The PCR reaction was carried out in a final volume of $50 \mu \mathrm{l}$ in $200 \mu \mathrm{l}$ thin walled tubes. The reaction was started with denaturation at $95^{\circ} \mathrm{C}$ for 5 min. The amplification profile involve 25 rounds of denaturation at $94^{\circ} \mathrm{C}$ for $30 \mathrm{~s}$, primers annealing at $48^{\circ} \mathrm{C}$ for $45 \mathrm{~s}$, and extension at $72^{\circ} \mathrm{C}$ for $90 \mathrm{~s}$ in a thermal cycler. An additional extension step at $72^{\circ} \mathrm{C}$ for $7 \mathrm{~min}$ was also included at the end of the thermal profile. The reaction tubes were held at $4^{\circ} \mathrm{C}$ after thermal cycling. PCR products were tested on $1.5 \%$ agarose gel electrophoresis by loading $5 \mu \mathrm{l}$ of the amplicon with the loading dye and visualization on UV after ethidium bromide staining.

Polyacrylamide Gel Electrophoresis (PAGE) and Quantitative Analysis: For quantitative analysis the PCR products were electrophoresed in a Genephor apparatus (Pharmacia Biotech) using ready made 10\% polyacrylamide gels (Pharmacia Biotech) at $150 \mathrm{~V}$, $25 \mathrm{~mA}$ and $15 \mathrm{~W}$ for 2 hours in $0.5 \mathrm{X}$ Tris-phosphate buffer to allow adequate resolution of the target and synthetic internal control. The gel was silver stained by DNA silver staining kit using Hoefer automated gel stainer (Pharmacia Biotech) or a manual procedure ${ }^{[23]}$. Each pair of signals on PAGE corresponding to the target template mRNA and the cRNA was analyzed by scanning densiotmetry (Hewlett Packard) and quantitated by IQ software (MD ImageQuant Software version 3.22). Quantitation of the target mRNA was performed by comparison with the cRNA internal 
standard and expressed per $\mu \mathrm{g}$ of total cellular RNA which leads to linear relationship between RNA concentration and mRNA copy number. The concentration of PDGF-A mRNA was calculated from the relative sample and control peak areas and the known number of molecules of cRNA added to the PCR reaction as described by Powell and Kroon ${ }^{[24]}$.

\section{RESULTS AND DISCUSSION}

A number of studies have previously been carried out to investigate the role of risk factors in the development of coronary heart disease (CHD) in diabetic and non diabetic subjects with normal or high levels of cholesterol ${ }^{[16,25,26]}$ but no consistent results have been reported. PDGF-A has also been investigated previously to study its possible role in the $\mathrm{CHD}^{[4,27]}$. However, the data available is conflicting and needs analysis at molecular level using reliable and reproducible method for more convincing results. Therefore, we quantified the expression of PDGF-A mRNA in four different groups of Saudi subjects using cRT-PCR, where a small synthetic RNA (pAW 109) was used as an internal standard (cRNA). The synthetic RNA control (pAW 109) has already been used in several previous studies as internal control ${ }^{[24]}$. The pAW 109 cRNA contains synthetic PCR primer sites for PDGF-A and a number of other genes thus serves as quantitative internal standard. The PCR primers used are RNA specific i.e. span exons only and therefore do not amplify the intervening sequences. Competitive RT-PCR products were detected by agarose gel electrophoresis and quantitation carried out on PAGE and silver staining. This represents an improvement over a previously published approach where a small synthetic RNA was used as an internal standard and detection system was based on radioactively labeled nucleotides that were incorporated during the amplification step ${ }^{[28]}$.

In the present study, blotting and radiation based detection system was replaced with silver staining, scanning densitometry and quantitation using computer software. The average PDGF-A mRNA copies or number of molecules/ $\mu \mathrm{g}$ of cellular RNA are $29 \pm 5 \times$ $10^{4}$ (values are mean $\pm \mathrm{SD}$ ) in group one (healthy subjects); $33 \pm 7 \times 10^{4}$ (group 2); $34 \pm 9 \times 10^{4}$ (group 3) and $41 \pm 4 \times 10^{4}$ (group 4). No significant difference in PDGF-A mRNA copies were observed among group 1, group 2 and group 3 whereas a significant increase was noticed in group 4 as compared to control (Fig. 1).

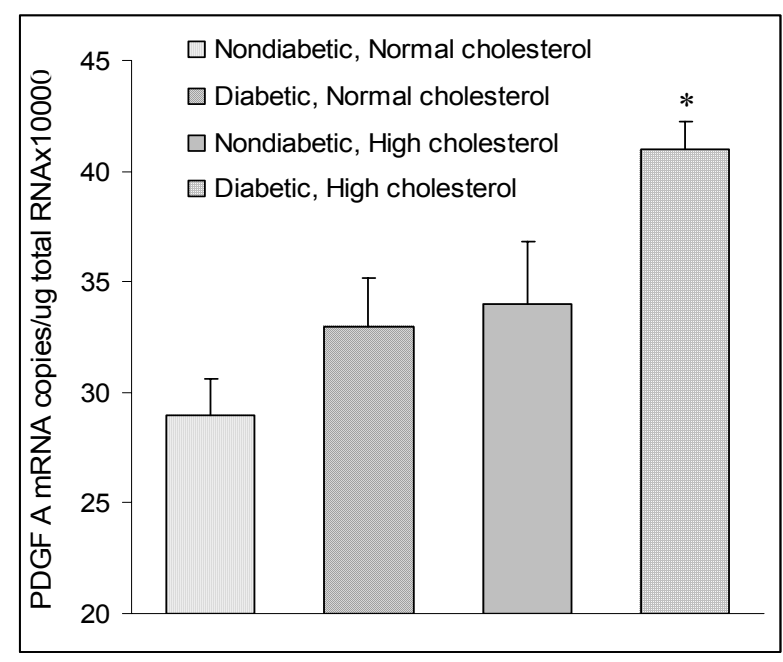

Fig. 1: $\quad$ PDGF-A mRNA copies/ $\mu$ g of total RNA in different groups. Values are mean \pm SEM. $* \mathrm{P}<0.05$ versus control (Nondiabetic, Normal cholesterol) group.

The previous reports indicate that PDGF play an important role in the proliferative process of atherosclerosis ${ }^{[29]}$. The association of high levels of PDGF-A mRNA in diabetic patients with high cholesterol indicates that it can be used as risk factor to predict the development of CHD in these individuals. High copy number of PDFG-A mRNA in diabetic and hypercholesteraemic patients represents some form of activation that might be associated with early stages of CHD.

It is important to establish whether this increase reflects the progress of atherogenesis in patients or PDGF-A mRNA levels are simply an early indicator of the initiation of the process. In either situation, the PDGF-A mRNA levels might represent a valuable non invasive tool to follow individuals at risk of atherosclerosis and a potential parameter for therapeutic intervention. Direct stimulation of PDGF-A gene by metabolites of cholesterol and hyperglycemia could be a simplest explanation, however, it is equally possible that some other factor may also be independently responsible for hypercholesteraemia and diabetes that raised PDGF-A mRNA, or that high cholesterol levels induce changes in cytokine signaling between endothelium, monocytes and/or other cells which initiates PDGF expression. A long term follow up of these subjects may provide more information to establish the role of PDGF-A mRNA as risk factor in the development of CHD. 


\section{REFERENCES}

1. Howard, B.V. et al., 1996. Diabetes and coronary heart disease in American Indians. Diabetes, 45 (3): 6-13.

2. Harker, L.A. et al., 1976. Homocystine-induced arteriosclerosis: the role of endothelial cell injury and platelet response in its genesis. J. Clin. Invest., 58: 731-41.

3. Friedman, R.J. et al., 1977. The effect of thrombocytopenia on experimental atherosclerotic lesion formation in rabbits. Smooth muscle cell proliferation and re-endothelialization. J. Clin. Invest., 60: 1191-01.

4. Bath PMW and J.F. Martin, 1991. Serum plateletderived growth factor and endothelin concentrations in human hypercholesterolaemia. J. Int. Med., 230: 313-7.

5. Nilsson, J., 1986. Growth factors and the pathogenesis of atherosclerosis. Atherosclerosis, 46: 185-9.

6. Nilsson, J. et al., 1986. Increased platelet-derived mitogenic activity in plasma of young patients with coronary atherosclerosis. Atherosclerosis, 61: 23743.

7. Westermark B, et al., 1983. Biochemistry and biology of platelet-derived growth factor. In: Growth and Maturation Factors. (Guraff Ed) pp 73115. Wiley and Sons, New York.

8. Antoniades, H.N., 1981. Human platelet-derived growth factor (PDGF): purification of PDGF-I and PDGF-II and separation of their reduced subunits. Proc. Natl. Acad. Sci., 78: 7314-7.

9. Raines, E.W. and R. Ross, 1986. Purification of human platelet derived growth factor. In: Methods in Enzymology, Vol 109, Hormone Action, Part I: Peptide Hormones.; (L Birnbaumer and BWO Malley editors) pp 749-73. Academic Press, New York.

10. Betsholtz, C., et al., 1986. cDNA sequence and chromosomal localization of human plateletderived growth factor A-chain and its expression in tumour cell line. Nature, 320 (24): 695-9.

11. Coulehan, J.L., et al., 1986. Acute myocardial infarction among Navajo Indians. Am. Public. Health, 76: 412-4.

12. Klain, M., et al., 1988. frequent diagnosis of acute myocardial infarction among Navajo Indians. Am. Public. Health, 78: 1351-2.

13. Hrabovsky, S.L., et al., 1989. Acute myocardial infarction and sudden death in Sioux Indians. West. J. Med., 150: 420-2.

14. Sobenin I.A., et al., 1996. Atherogenic modified LDL in diabetes. Diabetes, 45 (3): 35-9.

15. Pujia, A., et al., 1994. Common carotid arterial wall thickness in NIDDM subjects. Diabetes Care, 17 (11): 1330-6.

16. Anderson, J.L., et al., 1996. Diabetic macroangiopathy and atherosclerosis. Diabetes, 45 (3): 91-4.
17. Colwell, A. and M.F. Lopes-Virella, 1988. Review of the development of large-vessel disease in diabetes mellitus. The Am. J. Med., 85 (5A): 1138.

18. Powell, E.E. and P.A. Kroon, 1994. Low-density lipoprotein and 3-hydroxy-methylglutaryl coenzyme A reductase gene expression in human mononuclear leukocytes is regulated coordinately and parallels gene expression in human liver. J. Clin. Invest., 93 (5): 2168-74.

19. Xi, X., et al., 2001. Quantitation of telomerase components and hTERT mRNA splicing patterns in immortal human cells. Nucleic Acids Res., 29 (23): 4818-25.

20. David, R.B., et al., 2002. Quantitation of the mRNA levels of Epo and EpoR in various tissues in the ovine fetus. Mol. Cell Endocrinol., 188 (12): 207-18.

21. Kaminski, W.E., et al., 1993. Dietary $\omega-3$ fatty acids lower levels of platelet-derived growth factor mRNA in human mononuclear cells. Blood, 81 (7): 1871-9.

22. Chomezynski, P. and N. Sacchi, 1987. Single-step method of RNA isolation by acid guanidinium thiocyanate-phenol-chloroform extraction. Anal. Biochem., 162: 156-9.

23. Bassam, B.J., et al., 1991. Fast and sensitive staining of DNA in polyacrylamide gels. Anal. Biochem., 196: 81-4.

24. Powell, E.E. and P.A. Kroon. 1992. Measurement of mRNA by quantitative PCR with nonradioactive label. J. Lipid Res., 33: 609-14.

25. Watnabe, J., et al., 1988. Lopes-Virella MF. Enhancement of platelet aggregation by low density lipoproteins from IDDM patients. Diabetes, 37: 1652-7.

26. Oikawa, S., et al., 1996. Human arterial smooth muscle cell proliferation in diabetes. Diabetes, 45 (3): 114-6.

27. Nilsson, J., et al., 1992. Association between high levels of growth factors in Plasma and progression of coronary atherosclerosis. J. Int. Med., 232: 39704.

28. Alard, P., et al., 1993. A versatile ELISA-PCR assay for mRNA quantitation from a few cells. Biotechniques, 15 (4): 730-7.

29. Ross, R., et al., 1990. Localization of PDGF-B protein in macrophages in all phases of atherogenesis. Science, 248: 1009-12. 